\title{
Anthropogenic Impacts on the Distribution and Biodiversity of Benthic Macroinvertebrates and Water Quality of the Boufekrane River, Meknes, Morocco
}

\author{
L. Karrouch1', A. Chahlaoui' ${ }^{1}$, A. Essahale ${ }^{2}$ \\ ${ }^{1}$ Department of Biology, Faculty of Sciences Meknes, University of Moulay Ismail, Meknes, Morocco \\ ${ }^{2}$ Health-Environment Service, Provincial Delegation of Health, El Hajeb, Morocco \\ Email: karrouchlahcen@yahoo.fr
}

How to cite this paper: Karrouch, L., Chahlaoui, A. and Essahale, A. (2017) Anthropogenic Impacts on the Distribution and Biodiversity of Benthic Macroinvertebrates and Water Quality of the Boufekrane River, Meknes, Morocco. Journal of Geoscience and Environment Protection, 5, 173195.

https://doi.org/10.4236/gep.2017.57014

Received: April 11, 2017

Accepted: July 18, 2017

Published: July 21, 2017

Copyright () 2017 by authors and Scientific Research Publishing Inc. This work is licensed under the Creative Commons Attribution International License (CC BY 4.0).

http://creativecommons.org/licenses/by/4.0/

\section{c) (i) Open Access}

\begin{abstract}
The area of the city of Meknes (Morocco) undergoes anthropic pressure, which acts mainly on the rivers. River water is used, without preliminary treatment, for farm irrigation. A study of the impacts of anthropogenic activities on the distribution and biodiversity of benthic macroinvertebrates and water quality of the Boufekrane River (Meknes) was conducted. Four pristine stations from the upstream and two stations at the downstream receiving anthropogenic impacts were selected along the River. For 12 consecutive months (from January to December 2010), based on the SEQ-V.2 scoring system, water quality index classes, the upstream stations recorded significantly higher biological monitoring scores and better water quality indices than those of the downstream. Four variables are involved actively in the individualization of the physico-chemical environment: COD, dissolved oxygen, TSS and temperature. The total number of macrobenthic taxa and their overall richness indices and diversity indices were significantly higher at the upstream stations than at the downstream stations. The relationships between the physicochemical and the macrobenthic data were investigated by biotypology analysis (PCA and FCA) and Pearson correlation analysis. The analyses showed that the richness and diversity indices were generally influenced by the total suspended solids, chemical oxygen demand and the electric conductivity of the river water. This study also highlighted the impacts of anthropogenic activities on the distribution and species diversity of macrobenthic invertebrate. Some sensitive (Trichoptera and Ephemeroptera) and resistant species (Oligochaeta such as Tubifex sp.) are identified as potential bioindicators of clean and polluted river ecosystems, respectively, in Morocco rivers. The data obtained in this study supported the use of the bioindicator concept
\end{abstract}


(Innovative Biotechniques for controlling water quality) for North Africa rivers because it is more efficient than conventional methods.

\section{Keywords}

Water Quality, Benthic Macroinvertebrates, Anthropogenic Impacts, Meknes, Morocco

\section{Introduction}

The quantity and quality of water resources are the major issues threatening the economic and social development of Africa mainly for countries located at arid and semi-arid region [1]. In order to achieve sustainable development, environmental protection shall constitute an integral part of the development process [2] [3]. Water pollution is one of our most serious environmental problems. Pollutants that reach the aquatic environment are still a major environmental issue.

Studies of river macrobenthic invertebrates as biological monitoring techniques have been widely reported and described in the literature [4]-[12]. Freshwater macroinvertebrate species vary in sensitivity to organic pollution and, thus, their relative abundances have been used to make inferences about pollution loads. In natural pristine rivers, high diversity and richness of species is expected [13]. However, high impact due to human activities caused many changes to the assemblages and biodiversity of the river fauna [14]-[19].

The anthropogenic impacts on water quality and the distribution and diversity of macrobenthic invertebrates had been reported in the literature [20]. The elaboration and implementation of sustainable water treatment strategies should therefore be based on detailed data on the seasonal variation of the water quality that is strongly related to dilution processes taking place during high-flow periods, and to the loads of soluble compounds carried by the return waters utilized for land washing and irrigation [21].

In Morocco, awareness of environmental problems is rapidly increasing. In recent years, a growing number of studies stressed the critical situation of several Moroccan water courses [22] [23] [24] [25]. The Boufekrane River is the primary source of water for a variety of purposes (i.e. drinking, agriculture, industry, recreation). On the other hand, it receives wastes from vast rural areas and several large cities along its banks. The Meknes city is a striking example of the contamination pressure that a large city exerts on the Boufekrane River. Over the last few years, the region of Meknes experienced extensive industrial development. Major industrial activities include tanneries, brewery, textile, oil mills, canneries, blacksmith and pottery [26]. Industry brought important economic returns to the region of Meknes (e.g. generation of employment, improvement of living standards, etc); however, it resulted in considerable water quality degradation. Tanneries are among the most polluting industries in the region. Most 
operations are still being carried out traditionally and little attention is given to environmental and sanitary conditions both within and outside the workshops. The study presents a snapshot assessment of the water quality of the Boufekrane River based on the physical-chemical and benthic macroinvertebrates carried out in 2010.

This paper will hopefully try to address this lacuna by extending the information available through an analysis of the temporal and spatial variations in the quality of the Boufekrane waters and through a comment on the main factors lowering the quality levels. Tolerance of macroinvertebrates taxa to chemical and physical stress is widely used in the analysis and interpretation of bioassessment data for example Tubifex $s p$. that are considered resistent to different kinds of anthropogenic impacts. Nonetheless, the use of macrobenthic invertebrates for bioindication purposes seems not to be popular or widespread in the Maghrebin ecoregion although this technique provides a cheaper but good methodology in river classification and they are widely used in the Northern American and European ecoregions.

The objectives of this study are 1) to verify if the physicochemical parameters and the species diversity of the macrobenthic invertebrates differ significantly between upstream and downstream stations of the Boufekrane River and 2) to investigate the relationships between the physicochemical parameters and the biodiversity of macrobenthic invertebrates of the Boufekrane River, by using multiple stepwise regression analysis and correlation analysis (PCA, FCA and $t$ test comparisons), In order to identify the physicochemical parameters that could cause significant changes in the distribution and diversity of macrobenthic invertebrates.

\section{Material and Methods}

\subsection{Description of the Study Area and Sampling Sites}

The study area is situated in the North of Morocco (Figure 1). The area of Meknes formed a large part of the watershed river Sebou. Surveys and samplings were conducted from January to December 2010. We choose sixth stations in Boufekrane River (4 upstream stations and 2 downstream stations) for monitoring the degree of pollution and distribution of benthic macroinvertebrates. This river is used for recreational activities (washing, agricultural activity) especially during weak precipitation. Hydrogeological of the study area constituted by two important aquifers: The deep water aquifer $(\geq 150 \mathrm{~m})$ and the shallow aquifer $(\leq 20 \mathrm{~m})$. The waters of two aquifers are used for the supply of drinking water and also in irrigation and industry.

\subsubsection{Upstream Stations (Stations BF1-BF4)}

The first station (BF1) was located in Boufekrane River (Ain Maarouf source, reference site). The second station (BF2) was located near the Boufekrane village. The third and the fourth stations (BF3-BF4) were located upstream and downstream from Boufekrane village and upstream of the Meknes city. The water 


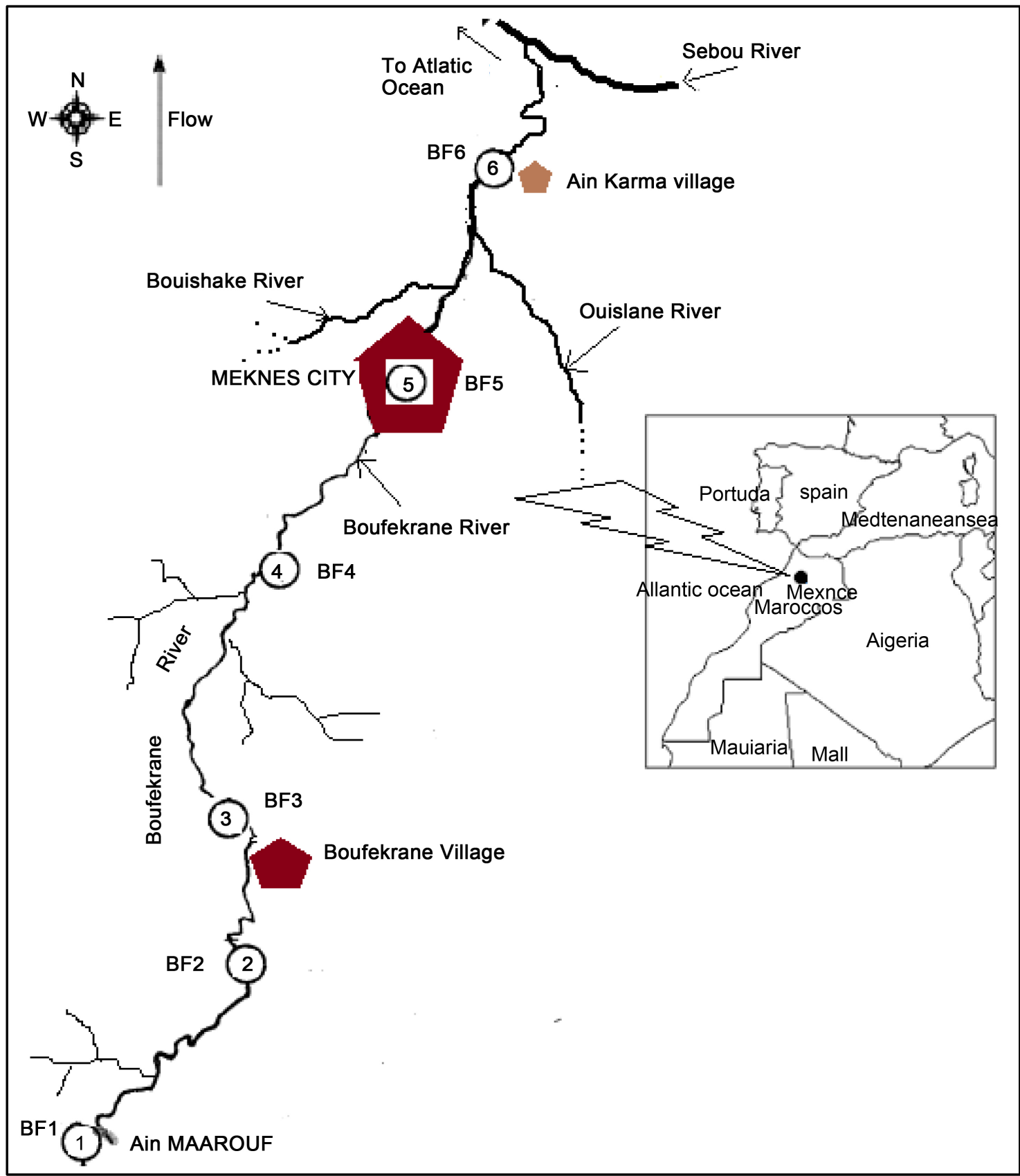

Figure 1. Sampling stations along the Boufekrane River.

was clean and clear and it was used by some villagers for irrigation, washing and bathing. There was generally high vegetation coverage at the four sampling stations.

\subsubsection{Downstream Stations (Stations BF5-BF6)}

The fifth station (BF5) was located in the Meknes city, meadows of the workshops traditional of tannery (El Fakharine). The sixth station (BF6) was located at the downstream of Meknes city and the village Ain Karma; this station receives the whole of the industrial and domestic wastes. The sediment was of a muddy type and contains a lot of organic matter due to sewage pollution. 


\subsection{Water Quality Measurement}

Four replicates of the physicochemical parameters were recorded directly at each sampling site. These were temperature, conductivity, $\mathrm{pH}$, and dissolved oxygen (DO). Four parameters were measured in situ using adequate sensors. The temperature and electric conductivity (EC) were measured by conductimeter CONSORT K 912, the water $\mathrm{pH}$ was measured by a $\mathrm{pH}$-meter HANNA $8519 \mathrm{~N}$ and dissolved Oxygen (DO) was measured by Oxymetrie THERMO ORION 810 .

Two replicates of water samples from each station were stored in polyethylene bottles $(500 \mathrm{ml})$. The water in the polyethylene bottles were preserved with $2 \mathrm{ml}$ of concentrated hydrochloric acid $(\mathrm{pH} \leq 2.0)$ and brought back to the laboratory. The water samples were kept in a refrigerator at a temperature below $4^{\circ} \mathrm{C}$ to stop all the activities and metabolism of the organisms in the water.

The biological oxygen demand (BOD), chemical oxygen demand (COD), sulphates, chlorides, total hardness, nitrate, orthophosphate and total suspended solids (TSS) were all determined in accordance with the standard method procedures of Rodier [27]. Afterward, the concentrations of nitrate, sulphate and orthophosphate were determined by using a spectrophotometer Model Hach Dr 2000 at a specified wavelength. Monthly measurements are regularly carried out on the level of the stations chosen during the period going the month January at December 2010.

\subsection{Data Collection}

The Sampling of the benthic macroinvertebrates responds to a standardized protocol French Association for Standardization (AFNOR) [28]. A Surber sampler (Mesh: $0.3 \mathrm{~mm}$; catching area: $0.1 \mathrm{~m}^{2}$ ) was used at sampling sites that had shallow running water substrates containing cobbles and pebbles (The Boufkarne River is a shallow stream with loose and coarse substrate). The Surber sampler was placed at the bottom against the flow. After the separation and sorting, all captured fauna were placed in plastic bottles and preserved with $80 \%$ ethanol.

In the laboratory, the benthic macroinvertebrates were sieved by using a column of three sieves with decreasing mesh $2 \mathrm{~mm}, 1 \mathrm{~mm}, 0.3 \mathrm{~mm}$, sorted into a petri dish, and identified by using taxonomic keys. The sorting and identification of the smaller fauna was done under a dissecting microscope. All the samples were preserved a in new pill with $80 \%$ ethanol before using the appropriate taxonomic keys. The specific identification was made using the original descriptions Moroccan (collections of the Scientific Institute of Rabat) and the Mediterranean.

The keys used in this study were [29] (aquatic oligochaetes of Morocco) [30] (Annelida and Oligochaeta), [31], (Crustacea), [32] (Mollusca) and [33] (Introduction to the study of freshwater macroinvertébrées). For insects, the keys used were, [34] (aquatic Heteroptera of Morocco commented Inventory), [35] (Preliminary Atlas of freshwater decapod crustaceans), [36] (Contribution to the knowledge of aquatic Coleoptera and Hemiptera Eastern Morocco: faunal cata- 
log), [37] and [38] (Diptera Chironomidae: aquatic larvae), and [39] (National Survey on Biodiversity continental fauna). Having been identified, the taxa are placed in glass pill containing either formaldehyde or ethanol for specimens whose shell or carapace may be destroyed by formalin (Crustaceans, Mollusks).

\subsection{Analysis of Data}

Water quality indices (WQI) and biotic index:

The evaluation of the biological conditions manifested by macrobenthic invertebrates was performed in three steps and based on calculation of quality indicators (Numerical evaluation):

1) The Biological Index Global Standardized (IBGN) is done according to the standard AFNOR 1992 [28].

2) Shannon-Wiener index $\left(H^{\prime}\right)$ :

$$
H^{\prime}=-\sum_{j=1}^{s} p_{j} \log p_{j}
$$

$S=$ total number of species; $p_{j}=$ proportional abundance or percentage of important, it is calculated as follows: $p_{j}=n_{j} / N_{T}$

$n_{j}=$ number of individuals of a species in the sample

$N_{T}=$ total number of individuals of all species in the sample.

3) Evenness Index $(E)$ :

$$
E=H^{\prime} / H_{\max }^{\prime} \text { with } H_{\max }^{\prime}=\log (s)
$$

$H^{\prime}$ : species diversity

$H_{\text {max }}^{\prime}:$ Logarithm $(\log 10)$ of the total number of species $(S)$ in the sample, were transformed prior to correlation analysis.

The biological quality scores of the Boufekrane River were based on the recommendations of the Biological Monitoring Working [40], where each family has a single score irrespective of the number of individuals or species recorded for the family.

* Transformation of data

Principal Component Analysis (PCA), Factorial Correspondence Analysis (FCA), $t$ test comparisons and descriptive analysis were performed using version 9 Software XLSTAT 2011 to identify the most influential variables affecting the biodiversity indices of the macrobenthic invertebrates. Principal Component Analysis (PCA) allows searching the groups of variables in the physical and chemical data set. These variables are sufficient to describe the variability of the whole group. Factorial Correspondence Analysis (FCA) allows establishing a typology and biotypology (to classify similar macroinvertebrate groups). These methods have been widely used in many areas related to the environment to highlight seasonal and anthropogenic influences on rivers [20] [41] [42] [43] [44] [45].

To expand the data matrix (to biotypology data), we used matrices in the form of tables of $\mathrm{n}$ species and $\mathrm{p}$ stations. For the numerical expression of the element $n p$, we opted the sum of the abundance of $n$ macrobenthic invertebrates and in 
every station p. For reduce the disparities between the abundances of taxa, we conducted a transformation of corresponding classes in abundance under a geometric progression of ratio 2 [46]. This semi-quantitative assessment still contains all the information needed for analysis (Table 1).

\section{Results and Discussion}

\subsection{Physical and Chemical Data}

Variations of $\mathrm{pH}$, temperature, electric conductivity (EC), $\mathrm{H}_{2} \mathrm{PO}_{4}^{-}, \mathrm{NO}_{3}^{-}$, $\mathrm{SO}_{4}^{2-}, \mathrm{Cl}^{-}, \mathrm{BOD}, \mathrm{COD}, \mathrm{DO}$, and TSS, and the $t$ test comparisons of mean values of the upstream and downstream are given in Table 2. The temperature shows an almost sinusoidal appearance with minima and maxima $\left(13^{\circ} \mathrm{C}\right.$ to $\left.26^{\circ} \mathrm{C}\right)$. In the periods of sampling, the downstream stations showed significantly $(\mathrm{P}<0.05)$ higher levels of $\mathrm{COD}, \mathrm{BOD}, \mathrm{PO}_{4}$, conductivity and TSS than the upstream stations. However, the upstream stations recorded significantly $(\mathrm{P}<0.05)$ higher levels of $\mathrm{pH}, \mathrm{O}_{2}$, and $\mathrm{NO}_{3}$ than the downstream stations.

The $\mathrm{pH}$ value is within the recommended range 6.5 e 8.5 for potability [46]. The DO level is $70 \%(6.96 \mathrm{mg} / \mathrm{l})$ saturation which is higher than the minimum (30\%, $2.43 \mathrm{mg} / \mathrm{l} \mathrm{DO}$ at $25.1^{\circ} \mathrm{C}$ ) required for protection of aquatic life [47] [48], TSS, $\mathrm{H}_{2} \mathrm{PO}_{4}^{-}, \mathrm{NO}_{3}^{-}, \mathrm{SO}_{4}^{2-}, \mathrm{Cl}^{-}, \mathrm{BOD}, \mathrm{COD}$ and conductivity values are low as compared to those in all the downstream sites. According to the SEQ-Eau V 2 (2003), the upstream sampling sites during the 12 sampling months in 2010 (Table 2) were categorized as good (clean; for recreational use with body contact) to slightly polluted (needing treatment in station BF3) while the downstream samples collected in June and September were categorized as poor water quality and upstream samples collected in October and April categorized as polluted (needing treatment for use irrigation).

It is evidenced from the physicochemical data that the upstream water quality was better than the downstream water quality during the period of sampling. The natural levels of $\mathrm{H}_{2} \mathrm{PO}_{4}^{-}$for riverine waters range from 0.5 to $3.05 \mathrm{mg} / \mathrm{l}$ [49], $\mathrm{H}_{2} \mathrm{PO}_{4}^{-}$contents at sites $\mathrm{BF} 5$ and $\mathrm{BF} 6$ fall outside this range (Table 3). Nitrate is toxic to aquatic life even at very low concentration [48]. Sample from downstream (BF 5 - 6) contain high concentrations of some major ions $\left(\mathrm{Cl}^{-}\right.$, $\mathrm{SO}_{4}^{2-}$ ), most probably originating from domestic water and tannery wastes (i.e. from the use of sulphuric acid, chromium sulphate and products with a chloride contents).

Table 1. Classes and range abundance restraint in biotypology study.

\begin{tabular}{cc}
\hline Classes & Range of abundance \\
\hline 0 & Absence \\
1 & {$[1.10]$} \\
2 & {$[11.100]$} \\
3 & {$[101.1000]$} \\
4 & Sup > 1000 \\
\hline
\end{tabular}


Table 2. Statistical description of the analytical data (physical and chemical data) (N: N of samples. Mean: average. S.E: Standard Error. S.L: Significance Level).

\begin{tabular}{|c|c|c|c|}
\hline Parameter & $\begin{array}{c}\text { Months in } \\
2010\end{array}$ & $\begin{array}{l}\text { Upstream } \\
\text { (BF } 1-4)\end{array}$ & $\begin{array}{c}\text { Downstream } \\
\text { (BF } 5 \text { - 6) }\end{array}$ \\
\hline \multirow{4}{*}{$\begin{array}{c}\text { Temperature } \\
\left({ }^{\circ} \mathrm{C}\right)\end{array}$} & $\mathrm{N}$ & 48 & 48 \\
\hline & Mean & 18.47 & 21.2 \\
\hline & S. E & 4.3 & 4.64 \\
\hline & S. L & $\mathrm{P}<0.05$ & $\mathrm{P}<0.05$ \\
\hline \multirow{4}{*}{$\mathrm{pH}$} & $\mathrm{N}$ & 48 & 48 \\
\hline & Mean & 7.33 & 6.73 \\
\hline & S. E & 0.16 & 0.11 \\
\hline & S. L & $\mathrm{P}<0.05$ & $\mathrm{P}<0.05$ \\
\hline \multirow{4}{*}{$\begin{array}{l}\text { Electric conductivity EC } \\
\qquad(\mu \mathrm{S} / \mathrm{cm})\end{array}$} & $\mathrm{N}$ & 48 & 48 \\
\hline & Mean & 827.75 & 1267 \\
\hline & S. E & 64.6 & 89.3 \\
\hline & S. L & $\mathrm{P}<0.05$ & $\mathrm{P}<0.05$ \\
\hline \multirow{4}{*}{$\begin{array}{l}\text { Dissolved oxygen } \\
\text { DO (mg/L) }\end{array}$} & $\mathrm{N}$ & 48 & 48 \\
\hline & Mean & 7.035 & 2.72 \\
\hline & S. E & 0.62 & 0.95 \\
\hline & S. L & $\mathrm{P}<0.05$ & $\mathrm{P}<0.05$ \\
\hline \multirow{4}{*}{$\begin{array}{c}\text { Biological oxygen } \\
\text { demand BOD }(\mathrm{mg} / \mathrm{L})\end{array}$} & $\mathrm{N}$ & 48 & 48 \\
\hline & Mean & 47.38 & 170 \\
\hline & S. E & 18.77 & 57.9 \\
\hline & S. L & $\mathrm{P}<0.05$ & $\mathrm{P}<0.05$ \\
\hline \multirow{4}{*}{$\begin{array}{c}\text { Chemical oxygen } \\
\text { demand COD } \\
(\mathrm{mg} / \mathrm{L})\end{array}$} & $\mathrm{N}$ & 48 & 48 \\
\hline & Mean & 97.74 & 383.5 \\
\hline & S. E & 38.02 & 105.1 \\
\hline & S. L & $\mathrm{P}<0.05$ & $\mathrm{P}<0.05$ \\
\hline \multirow{4}{*}{$\begin{array}{l}\text { Orthophosphate } \\
\mathrm{H}_{2} \mathrm{PO}_{4}^{-} \quad(\mathrm{mg} / \mathrm{L})\end{array}$} & $\mathrm{N}$ & 48 & 48 \\
\hline & Mean & 7.93 & 24.7 \\
\hline & S. E & 2.73 & 4.6 \\
\hline & S. L & $\mathrm{P}<0.05$ & $\mathrm{P}<0.05$ \\
\hline \multirow{4}{*}{$\begin{array}{c}\text { Nitrate } \\
\mathrm{NO}_{3}^{-}(\mathrm{mg} / \mathrm{L})\end{array}$} & $\mathrm{N}$ & 48 & 48 \\
\hline & Mean & 3.73 & 2.02 \\
\hline & S. E & 1.13 & 0.76 \\
\hline & S. L & $\mathrm{P}<0.05$ & $\mathrm{P}<0.05$ \\
\hline \multirow{4}{*}{$\begin{array}{c}\text { Chloride } \\
\mathrm{Cl}^{-} \quad(\mathrm{mg} / \mathrm{L})\end{array}$} & $\mathrm{N}$ & 48 & 48 \\
\hline & Mean & 276.5 & 499 \\
\hline & S. E & 69.37 & 101.54 \\
\hline & S. L & $\mathrm{P}<0.05$ & $\mathrm{P}<0.05$ \\
\hline \multirow{4}{*}{$\begin{array}{c}\text { Sulfate } \\
\mathrm{SO}_{4}^{2-} \quad(\mathrm{mg} / \mathrm{L})\end{array}$} & $\mathrm{N}$ & 48 & 48 \\
\hline & Mean & 9.45 & 19.3 \\
\hline & S. E & 2.8 & 3.64 \\
\hline & S. L & $\mathrm{P}<0.05$ & $\mathrm{P}<0.05$ \\
\hline \multirow{4}{*}{$\begin{array}{c}\text { Total hardness } \\
\mathrm{TH}\left({ }^{\circ} \mathrm{F}\right) \\
\left(1^{\circ} \mathrm{F}=10 \mathrm{mg} / \mathrm{l}\right)\end{array}$} & $\mathrm{N}$ & 48 & 48 \\
\hline & Mean & 48.75 & 60.75 \\
\hline & S. E & 5.04 & 5.45 \\
\hline & S. L & $\mathrm{P}<0.05$ & $\mathrm{P}<0.05$ \\
\hline \multirow{4}{*}{$\begin{array}{l}\text { Total suspended solids } \\
\text { TSS }(\mathrm{mg} / \mathrm{L})\end{array}$} & $\mathrm{N}$ & 48 & 48 \\
\hline & Mean & 1304.25 & 5746 \\
\hline & S. E & 508.75 & 1173.5 \\
\hline & S. L & $\mathrm{P}<0.05$ & $\mathrm{P}<0.05$ \\
\hline
\end{tabular}


Table 3. Pearson's correlation of physical and chemical data of the Boufekrane River (2010).

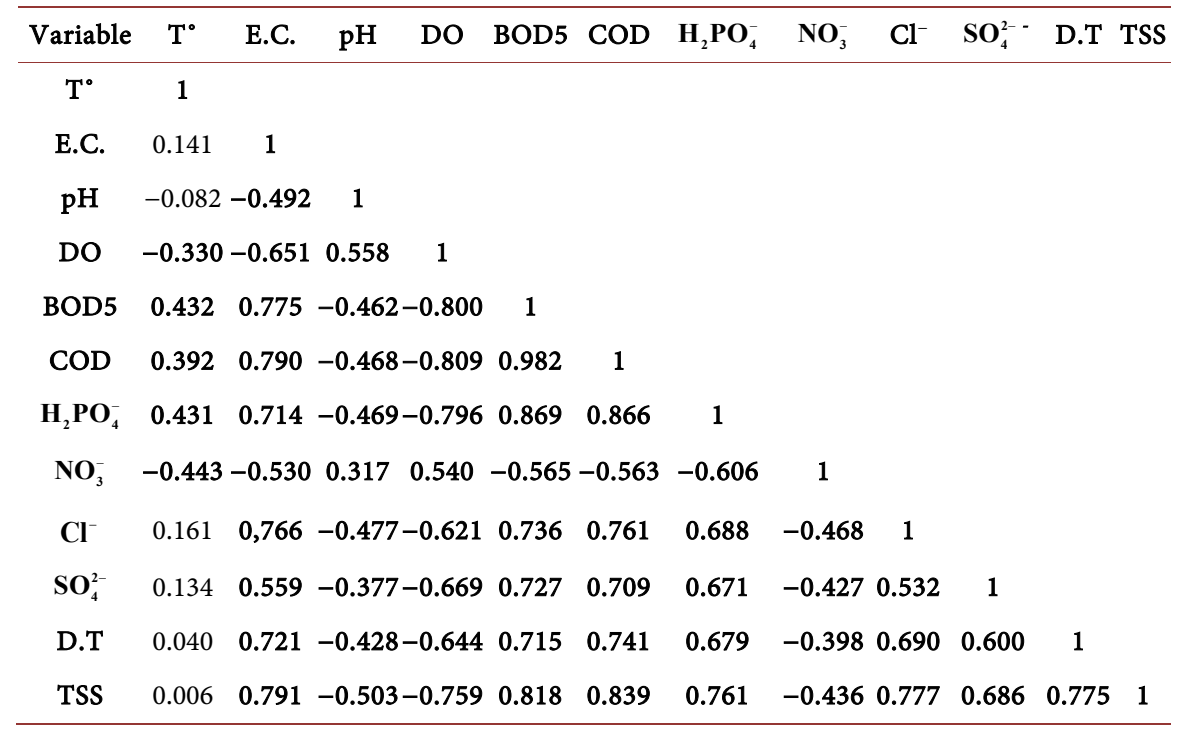

The major contributors to water pollution in this section are industrial facilities (tanneries, brewery, textile, pottery, etc.) scattered in the region. Sewage and urban waste-water, from town and from several nearby settlements, constitute other discharges that are negatively affecting the water quality in the region [24] [50].

Pearson's correlation of physical and chemical data of the Boufekrane River is given in Table 3 . The dissolved oxygen, nitrate and $\mathrm{pH}$ were negatively correlated with other parameters. The biological oxygen demand (BOD) and chemical oxygen demand (COD) are fairly strongly correlated with each other ( $\mathrm{r}$ $($ DCO-DBO5) $\geq 0.95)$. However, oxygen $\left(\mathrm{O}_{2}\right)$ and chemical oxygen demand $(\mathrm{r}$ $\mathrm{O} 2-\mathrm{DCO}) \leq-0.809$ ). This could be explained by the increase of organic matter resulting in decreased oxygen levels in the water.

The principal component analysis (PCA) was performed for all quantitative variables studied. The results of this analysis show that the first three factorial axes (F1, F2 and F3) help to explain more than $80 \%$ of the total variation (Table 4). In the general case, a better representation of the point cloud in this factorial design is shown by a lot of inertia [51] [52]. The eigenvalues (Table 4) show that the majority of information is mainly explained by the first two factorial axes F1 and F2, which represent more than $75 \%$ of the total inertia.

The correlation circle (Figure 2) clearly shows that the temperature, electric conductivity (EC), sulfates, chlorides, suspended solids, orthophosphate, COD, BOD and total hardness are positively correlated with the first principal component $\mathrm{F} 1, \mathrm{pH}$, dissolved oxygen and nitrates are negatively associated with this axis. We observe that the main axis F1 have primarily and exclusively organic character variant. They are very close to the correlation circle; participate in a major way in the formation of the F1 axis, while the main F2 represents the mineral character axis. 
Principal component analysis (PCA) of Boufekrane Rive (Figure 3) shows 4 groups:

Table 4. Contribution of the first three axes of the total variance, Boufekrane River.

\begin{tabular}{cccc}
\hline & F1 & F2 & F3 \\
\hline Eigen value & 7.690 & 1.316 & 0.712 \\
Variability (\%) & 64.080 & 10.969 & 5.937 \\
Cumulative \% & 64.080 & 75.048 & 80.985 \\
\hline
\end{tabular}

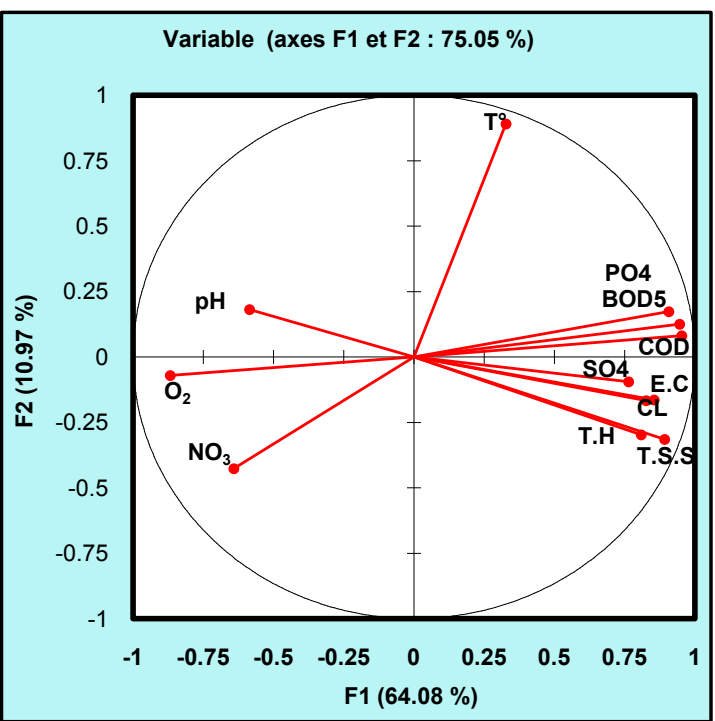

Figure 2. Correlation circle Principal Component Analysis (PCA) of the physical and chemical data of Boufekrane River.

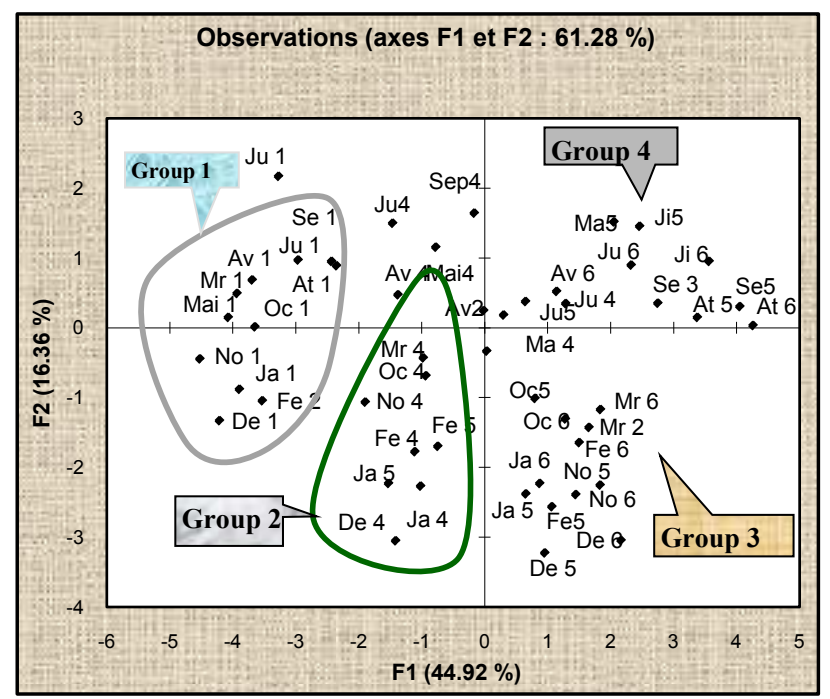

Figure 3. Principal Component analysis (PCA) specimen on the plane F1 $\times$ F2 of Boufekrane. 1: station 1 (BF1); 2: station 2 (BF2); 3: station 3 (BF3); 4: station 4 (BF4); 5: station 5 (BF5); 6: station 6 (BF6). Ja: January; Fe: February; Mr: March; Ap: April; Ma: May; Ju: June; Ji: July; At: August; Se: September; Oc: October; No: November; De: December. 
Group 1: This group consists exclusively of individuals 1 (station BF1), scattered and poorly coordinated positively on component 1 . The waters of this group are weakly charged organic matter and well-oxygenated.

Group 2: It is mainly formed by 12 samples that have negative coordinates on axis 1 with the exception of individuals Ap2, Ma2, Ju4, Sep4 and Ma4. The dispersion of samples in this group is much higher along the component 2 (mineral component).

Groups 3 and 4: These two groups consist of samples for stations BF5 and BF6. They contain $45 \%$ of all samples studied, positive coordinates compared principal 1 (F1) and highly loaded with organic matter. This group is characterized by a high mineralization during the summer period. Indeed, the reduction of inputs of water and the temperature increase causes an enrichment of water chlorides, nitrates, sulfates, and TSS, which results in an increase in the COD and elevated mineralization leading to an increase of the water contamination.

\subsection{Macrobenthic Invertebrate Data}

Macrobenthic invertebrates found at the upstream and downstream sampling sites of the Boufekrane River are shown in Table 5. By combining all 12 sampling months, there were a total of 126 taxa dominating the upstream stations (BF1-4) while at the downstream stations (BF5-6) there were only 26 taxa found (Table 5).

Tubificidae (a family within Oligochaeta) also appeared consistently at the 2 downstream stations during the 12 sampling months. According to the SEQ-V.2 scoring system, (BF1:123; BF4:66) the upstream stations for the 12 sampling months were categorized as "good water quality" while the scores (BF5:26; BF6:14) for the downstream were categorized as "poor water quality."

Comparisons of richness indices, diversity indices (Shannon-Weaner and Evenness), and Biotic index between upstream and downstream are presented in Table 6. The four biodiversity indices (richness indices SR, Biotic index IBGN, Shannon-Weaner H' and evenness index E) gave better information about the environmental conditions where the organisms lived than a consideration of the individual taxa alone [53] [54].

It is clearly shown that the Taxonomic richness (SR), Biotic index (IBGN), and diversity indices [Shannon-Weaner $(H)$, Evenness Index $(\mathrm{E})]$ are significantly $(\mathrm{P}<0.001)$ higher in the upstream than in the downstream.

Although the values calculated here are for representation, these numbers indicate an increase in the dominance by fewer species especially at the downstream stations. This phenomenon was indicated by the evenness index (E) which is significantly $(\mathrm{P} \leq 0.001)$ lower in the upstream than in the downstream of the Boufekrane River $\left(\mathrm{E}_{\max }=0.6\right)$. For taxa richness, the number of taxa present is one measure of biodiversity [55].

\subsection{Biotypology Analysis}

The Factorial Correspondence Analysis (FCA) is shown in Figure 4. Table 5 
Table 5. Macrobenthic invertebrates and their ranges of abundance found at the upstream (stations 1 - 4) and downstream (stations 5 - 6) and codes of each species of the Boufekrane River.

\begin{tabular}{|c|c|c|c|c|c|c|c|}
\hline \multirow{3}{*}{ Species } & \multirow{3}{*}{$\begin{array}{c}\begin{array}{c}\text { Code of } \\
\text { each } \\
\text { species }\end{array} \\
\text { E }\end{array}$} & \multicolumn{6}{|c|}{ Stations Boufekrane River } \\
\hline & & \multicolumn{4}{|c|}{ Upstream (stations $1-4)$} & \multicolumn{2}{|c|}{$\begin{array}{c}\text { Downstream } \\
\text { (stations } 5-6 \text { ) }\end{array}$} \\
\hline & & BF1 & BF2 & BF3 & BF4 & BF5 & BF6 \\
\hline Polycelis felina & $\mathrm{E} 1$ & 16 & 12 & & & & \\
\hline Polycelis nigra & E2 & 4 & 4 & & & & \\
\hline Polycelis tenuis & E3 & 3 & 1 & 3 & & & \\
\hline Phagocata sp. & $\mathrm{E} 4$ & 4 & & 2 & & & \\
\hline Dugesia lugubris & E5 & 3 & 1 & & & & \\
\hline Dugesia polychroa & E6 & 3 & & & & & \\
\hline Dugesia gonocephala & E7 & 1 & & & & & \\
\hline Dugesia tigrina & $\mathrm{E} 8$ & 2 & & & & & \\
\hline Dendrocoelum lacteum & E9 & 3 & & & & & \\
\hline Potamodrlus sp. & E10 & 2 & & & & & \\
\hline Gordiace sp. & E11 & 0 & & 2 & & 4 & \\
\hline Glassiphonia complanata & E12 & 4 & 14 & 2 & 5 & & \\
\hline Hemiclepsis sp. & E13 & 1 & 7 & & 2 & & \\
\hline Helobdella sp. & E14 & 1 & 11 & & 1 & & \\
\hline Piscicola sp. & E15 & 2 & & & & & \\
\hline Hirudo sanguisuga & E16 & 30 & 12 & 5 & 7 & 12 & \\
\hline Hirudo medicinalis & E17 & 3 & 17 & & 6 & & \\
\hline Nais christane & E18 & & & & & 18 & \\
\hline Nais pardalis & E19 & & & & & 23 & \\
\hline Stylaria sp. & E20 & & & & & 32 & 3 \\
\hline Lumbriculus variegatus & E21 & & & & & 10 & 453 \\
\hline Enchytraeus sp. & E22 & & & & & 13 & 65 \\
\hline Eiseniella tetraedra & E23 & & & & & 34 & 34 \\
\hline Branchiura sowerbyid & E24 & & & & & 94 & 54 \\
\hline Aulodrilus limnobus & E25 & & & 11 & & 65 & 76 \\
\hline Tubifex tubifex & E26 & & & 2 & & 35 & 326 \\
\hline Tubifex ignotus & E27 & & & & & 67 & 678 \\
\hline Valvata piscinalis & E28 & 102 & 34 & 12 & 13 & & \\
\hline Valvata minuta & E29 & 15 & 8 & & & & \\
\hline Valvata fagoti & E30 & 10 & 2 & & 2 & & 4 \\
\hline Valvata globulina & E31 & 22 & 34 & 13 & 34 & & 3 \\
\hline Valvata moquini & E32 & 12 & 1 & 6 & 7 & & \\
\hline Valvata cristata & E33 & 18 & 3 & 13 & 2 & & \\
\hline Valvata exilis & E34 & 2 & 1 & 1 & & & \\
\hline Viviparus vivipara & E35 & 11 & 8 & 2 & 12 & & \\
\hline Viviparus fasciata & E36 & 3 & 9 & & 1 & & \\
\hline
\end{tabular}




\section{Continued}

\begin{tabular}{|c|c|c|c|c|c|c|c|}
\hline Viviparus bourguignati & E37 & 2 & 5 & & 8 & & \\
\hline Bithynia tentaculata & E38 & 67 & 106 & 45 & 78 & & \\
\hline Bithynia leachi & E39 & 130 & 93 & 12 & 20 & & \\
\hline Bithynia celtica & $\mathrm{E} 40$ & 3 & 2 & 3 & 4 & & \\
\hline Bythinella viridis & $\mathrm{E} 41$ & 97 & 67 & 9 & 12 & & \\
\hline Bythinella turgida & $\mathrm{E} 42$ & 5 & 5 & 4 & 8 & & \\
\hline Bythinella bicarinata & E43 & 1 & 9 & & 4 & & \\
\hline Bythinella bervis & $\mathrm{E} 44$ & 5 & 4 & & 5 & & \\
\hline Potamopyrgus mercuria & E45 & 12 & 45 & 23 & 34 & & \\
\hline Potamopyrgus confusa & E46 & 34 & 18 & 12 & 23 & & \\
\hline Hydrobia sp. & E47 & 3 & 12 & 43 & 19 & & \\
\hline Neritia fluviatilis & $\mathrm{E} 48$ & 22 & 45 & 15 & 45 & & \\
\hline Neritia Theodoxus & E49 & 2 & 87 & & 3 & & \\
\hline Smaragdia viridis & E50 & 3 & 4 & & 1 & & \\
\hline Physa acuta & E51 & 760 & 340 & 106 & 139 & & \\
\hline Planorbis planorbis & E52 & 760 & 245 & 35 & 68 & & \\
\hline Planorbis metidjensis & E53 & 5 & 18 & 12 & 23 & & \\
\hline Gyraulus laevis & E54 & 1 & 8 & 4 & 4 & & \\
\hline Acroloxus lacustris & E55 & 3 & 13 & & & & \\
\hline Succinea debilis & E56 & 12 & 5 & & 3 & & \\
\hline lymnaea peregra & E57 & 55 & 177 & 24 & 12 & 12 & \\
\hline lymnaea truncatula & E58 & 34 & 145 & 37 & 36 & 10 & \\
\hline Lymnaea stagnalis & E59 & 13 & 2 & 2 & 1 & & \\
\hline Lymnaea sp. & E60 & 2 & 7 & 3 & 5 & & \\
\hline lymnaea palustris & E61 & 5 & 4 & 3 & 2 & & \\
\hline Melanopsis praemorsa & E62 & 3356 & 2563 & 198 & 318 & 12 & 13 \\
\hline Melanopsis scalaris & E63 & 1084 & 968 & 257 & 215 & 23 & 3 \\
\hline Melanopsis mourebeyens & E64 & 789 & 408 & 78 & 34 & 12 & 5 \\
\hline Melanopsis costellata & E65 & 957 & 560 & 133 & 87 & 16 & 12 \\
\hline Ancylus fluviatilis & E66 & 5 & 6 & 2 & 9 & & \\
\hline Pisidum casertanum & E67 & 1 & 7 & & 6 & & \\
\hline Unio durieui & E68 & 10 & 3 & & 1 & & \\
\hline Unio cygnea & E69 & 1 & 5 & 1 & 3 & & \\
\hline Gammarus gauthieri & E70 & 32 & & & & & \\
\hline Gammarus rouxi & E71 & 23 & 6 & & & & \\
\hline Proaselus sp. & E72 & 1 & 3 & & & & \\
\hline Leptestheria mayeti & E73 & 36 & 97 & & 48 & & \\
\hline Hydrometra stagnorum & E74 & 8 & 16 & & 10 & 2 & \\
\hline Hebrus curtis & E75 & 2 & 7 & & & & \\
\hline Mesovelia fureatu & E76 & 2 & & & & & \\
\hline Velia caprai & E77 & 3 & 7 & & & & \\
\hline
\end{tabular}




\section{Continued}

\begin{tabular}{|c|c|c|c|c|c|c|c|}
\hline Gerris thoracius & E78 & 7 & 45 & 12 & 12 & 3 & \\
\hline Notonecta sp. & E79 & 5 & 8 & & & & \\
\hline Nepa cinerea & E80 & 2 & 32 & 6 & 14 & & \\
\hline Nepa linearis & E81 & 4 & 7 & 2 & 17 & & \\
\hline Plea leachi & E82 & 2 & 8 & 4 & 2 & & \\
\hline Naucoris maculatus & E83 & 1 & 4 & & 1 & & \\
\hline Aphelocheirus aestivalis & E84 & 3 & 1 & 2 & & & \\
\hline Ghomphus sp. & E85 & 4 & & & 5 & & \\
\hline Cordulegaster sp. & E86 & 2 & & & & & \\
\hline Calopteryx sp. & E87 & 5 & 7 & 3 & & & \\
\hline Sympcema fusca. & E88 & 1 & & & 1 & & \\
\hline Platycnemis subdilatata. & E89 & 1 & 2 & & & & \\
\hline Perla sp. & E90 & 4 & 7 & 3 & 1 & & \\
\hline Brachypter sp. & E91 & 1 & 9 & & & & \\
\hline Tyrhenoleuctra sp. & E92 & 3 & 5 & 5 & 3 & & \\
\hline Ephemera glaucop & E93 & 1 & 5 & 8 & & & \\
\hline Ephoron virgo & E84 & 3 & 9 & 1 & & & \\
\hline Potamathus luteus & E95 & 2 & 6 & & & & \\
\hline Oligoneuriella skour & E96 & 2 & 19 & 5 & 1 & & \\
\hline Ecdyonurus rothschildi & E97 & 2 & 11 & & & & \\
\hline Epeorus sp. & E98 & 2 & 9 & 3 & 9 & 1 & \\
\hline Rhithrogena sp. & E99 & & 35 & 2 & 5 & 2 & \\
\hline Caenis luctuosa & E100 & 2 & 9 & 5 & & & \\
\hline Baetis fuscatus & E101 & 3 & 23 & 1 & 9 & & \\
\hline Baetis muticus & E102 & 2 & 19 & & 2 & & \\
\hline Baetis rhodani & E103 & 1 & 8 & & & & \\
\hline Ephemerlla ignita & E104 & 3 & 9 & & & & \\
\hline Procloeon sp. & E105 & & 4 & & & & \\
\hline Paraleptophlebia sp. & E106 & 4 & 4 & & & & \\
\hline Choroterpes pictéti & E107 & 1 & 6 & & & & \\
\hline Chironomus thumni & E108 & 67 & 34 & 5 & 6 & 16 & 63 \\
\hline Chironomus halophilus & E109 & 34 & 8 & 2 & 8 & 12 & \\
\hline Corynoneura sp. & E110 & 4 & 3 & 4 & 3 & & \\
\hline Tanytarsus sp. & E111 & 3 & 22 & 3 & 5 & & \\
\hline Chaoborus crystallinus & E112 & & 3 & & & & \\
\hline Eristalis sp. & E113 & & & 2 & & & \\
\hline Simulium $s p$ & E114 & & 6 & 1 & & & \\
\hline Hemerodromia todrhana & E115 & 1 & 2 & & & & \\
\hline Rhyacophila sp. & E116 & 2 & 6 & & 2 & & \\
\hline Ecnomus deceptor & E117 & 9 & 11 & & & & \\
\hline Philopotamus sp. & E118 & 1 & 5 & & & & \\
\hline
\end{tabular}




\section{Continued}

\begin{tabular}{|c|c|c|c|c|c|}
\hline Psychomia sp. & E119 & & & 2 & 1 \\
\hline Hdroptila sp. & E120 & & 8 & & \\
\hline Agapetus sp. & E121 & 2 & 3 & & \\
\hline Silonella aurata. & E122 & 3 & 6 & & \\
\hline Dryops sp. & E123 & 9 & 8 & & 4 \\
\hline Agabus nebulosus & E124 & 1 & 6 & & \\
\hline Hydrochus sp. & E125 & 3 & & & \\
\hline Gyrinus urinator & E126 & 3 & 6 & & \\
\hline Elmis maugetii & E127 & 2 & 12 & & 3 \\
\hline Haliplus sp. & E128 & & 4 & & \\
\hline Helophorus sp. & E129 & & 2 & & \\
\hline Hdreana sp. & E130 & 4 & 5 & & 2 \\
\hline Laccobius gracilis & E131 & 2 & 4 & & 5 \\
\hline Limnebius sp. & E132 & 8 & 5 & & 7 \\
\hline Coelostoma sp. & E133 & & 7 & & 2 \\
\hline Hygdrobia Tarda & E134 & 1 & 4 & 1 & 2 \\
\hline
\end{tabular}

Table 6. t-test results from comparisons of mean ( \pm standard error) values of richness indices (SR), diversity indices (Shannon-Weaner $H$ and Evenness index (E) between upstream (stations 1 - 4) and downstream (stations 5 - 6).

\begin{tabular}{cccc}
\hline $\begin{array}{c}\text { Water quality indices } \\
\text { (WQI) }\end{array}$ & $\begin{array}{c}\text { Upstream } \\
(\mathrm{BF} 1-4)\end{array}$ & $\begin{array}{c}\text { Downstream } \\
(\mathrm{BF} 5-6)\end{array}$ & Significance \\
\hline Taxonomic richness (SR) & $91 \pm 29.5(\min 60-\max 118)$ & $16 \pm 5.6(\min 12-\max 20)$ & $\mathrm{P}<0.001$ \\
Biotic index: I.B.G.N & $16 \pm 4.08(12-20)$ & $4.5 \pm 2.12(3-6)$ & $\mathrm{P}<0.001$ \\
Shannon-Weaner $\left(H^{+}\right)$ & $1.07 \pm 0.08(0.96-1.16)$ & $0.65 \pm 0.28(0.45-0.85)$ & $\mathrm{P}<0.001$ \\
Evenness Index (E) & $0.55 \pm 0.01(0.54-0.57)$ & $0.48 \pm 0.16(0.37-0.6)$ & $\mathrm{P}<0.001$ \\
\hline
\end{tabular}

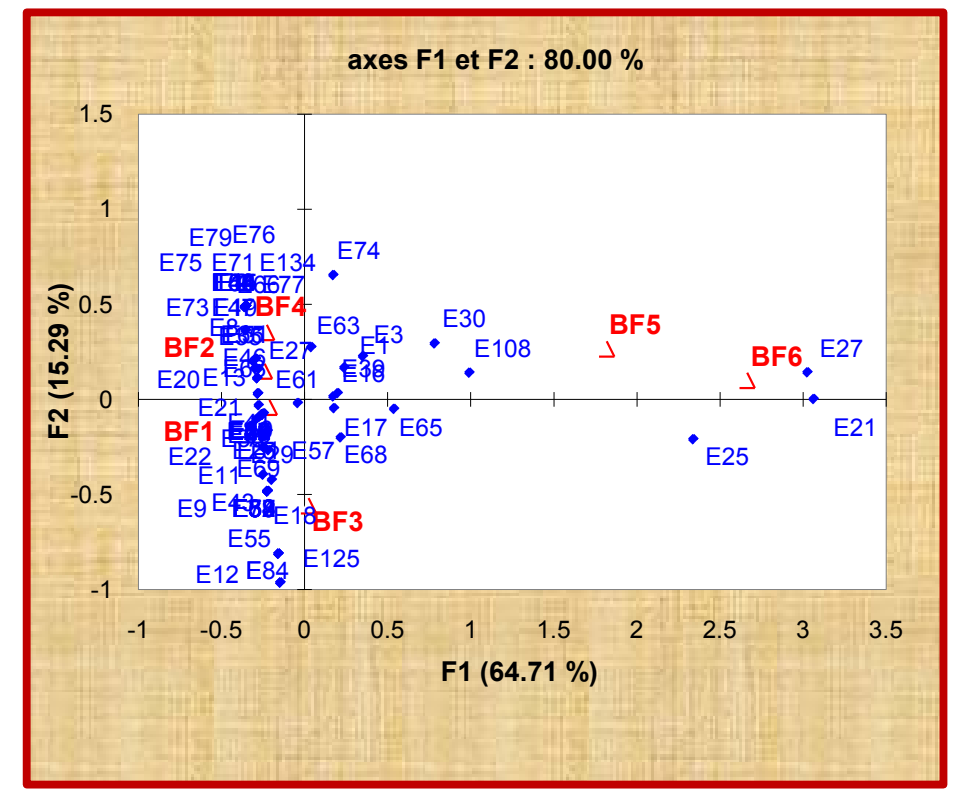

Figure 4. Factorial Correspondence Analysis (FCA) for benthic macroinvertebrates according to sampling sites (Boufekrane River 2010). $\Delta$ : Station, $\triangleleft$ : Species. 
represents the data matrix and codes of each species. The percentage of inertia of the first two axes totals nearly $80 \%$ of the information (Figure 4 ).

$\checkmark$ On axis 1 (Figure 4), three species of Oligochaeta have a strong contribution: Tubifex tubifex (E27), Lumbriculus variegatus (E21), Helodrilus limnobium (E25) and to a lesser degree Valvata fagoti (E30), Melanopsis costellata (E65) and Chironomus thummi (E108). The first factor reflects the relative importance of 6 species. These species characterize BF5 and BF6, corresponding to the most polluted stations.

$\checkmark$ On axis 2, the highest contributions are due to Hydrochus sp. (E125), $H_{y}$ drometra stagnorum (E74), Lymnaea peregra (E57), Ephoron virgo (E84), Hygrobia tarda (E134) Melanopsis scalari (E63) and other species have an influence very low in the plan $1-2$. The BF3 station has a strong contribution to this axis and the slightest degree BF4 station.

\subsection{Discussion of Physical-Chemical Parameters and Biological Indices}

In the upstream stations, the four biodiversity indices (richness indices SR, Shannon-Weaner $H$ and Evenness Indice (E) were significantly influenced by dissolved oxygen (DO), nitrate $\left(\mathrm{NO}_{3}^{-}\right)$and $\mathrm{pH}$. However, for downstream stations, these indices were influenced by biochemical oxygen demand (BOD), chemical oxygen demand (COD), total suspended solids (TSS) and conductivity (Cond). The richness, diversity, and evenness indices at the upstream and downstream sampling sites during the 12 months of sampling appeared to respond to the water quality deterioration (Table 5 and Table 6). High species diversity at the upstream was associated with unpolluted conditions, while lower species biodiversity often signified environmental stress due to human activities.

Pearson's correlation of coefficients of diversity indices and physicochemical data of the Boufekrane River are presented in Table 7. The three diversity indices (RS, Biotic index, and $H^{\prime}$ ) were significantly influenced by TSS, conductivity and $\mathrm{H}_{2} \mathrm{PO}_{4}^{-}$(negatively proportional $\mathrm{r} \geq-0.68$ ). From the correlation analysis (CA) (Table 7), Taxonomic richness (RS), Biotic index (IBGN) and ShannonWeaner $(H)$ were negatively and significantly $(\mathrm{P}<0.001)$ correlated with TSS $(\mathrm{r}=-0.86, \mathrm{r}=-0.82, \mathrm{r}=0.84)$, E.C $(\mathrm{r}=-0.84, \mathrm{r}=-0.90, \mathrm{r}=-0.83)$ and $\mathrm{H}_{2} \mathrm{PO}_{4}^{-}$ $(\mathrm{r}=-0.85 ; \mathrm{r}=-0.80, \mathrm{r}=-0.69)$.

Table 7. Pearson's correlation of coefficients of diversity indices and physical-chemical data of the boufekrane river.

\begin{tabular}{|c|c|c|c|c|c|c|c|}
\hline & DO & TSS & $\mathrm{T}$ & BOD & E.C. & COD & $\mathrm{H}_{2} \mathrm{PO}_{4}^{-}$ \\
\hline Taxonomic richness (SR) & $0.89^{* * *}$ & $-0.86^{\star * *}$ & $-0.57^{\star \star}$ & -0.5 & $-0.84^{\star * *}$ & -0.6 & $-0.85^{\star \star *}$ \\
\hline Biotic index: I.B.G.N & $0.92^{\star * *}$ & $-0.82^{\star * *}$ & $-0.63^{\star \star}$ & $-0.60^{* *}$ & $-0.90^{* * *}$ & $-0.62^{\star * *}$ & $-0.80^{* * *}$ \\
\hline Shannon-Weaner $(H)$ & $0.84^{* * *}$ & $-0.84^{\star * *}$ & $-0.69^{* * *}$ & $-0.57^{\star * *}$ & $-0.83^{* * *}$ & $-0.24^{*}$ & $-0.69^{* * *}$ \\
\hline Evenness Index (E) & $-0.68^{* * *}$ & $0.62^{\star * *}$ & $0.45^{\star \star}$ & $0.42^{\star * *}$ & $0.73^{\star \star *}$ & $0.21^{\star}$ & $0.52^{\star * *}$ \\
\hline
\end{tabular}

TSS: total suspended solids; DO: dissolved oxygen; BOD: biological oxygen demand; COD: chemical oxygen demand; $\mathrm{H}_{2} \mathrm{PO}_{4}^{-}$: Orthophosphate; T: temperature; E.C.: Electric Conductivity. Values given are the correlation coefficients $(\mathrm{r})$ and their levels of significance $\left({ }^{\star} \mathrm{P}<0.05 ;{ }^{\star *} \mathrm{P}<0.01 ;{ }^{* \star} \mathrm{P}<0.001\right)$. 
In addition, Taxonomic richness (SR) was negatively and significantly influenced by the biological oxygen demand (BOD, $\mathrm{r}=-0.59, \mathrm{P}<0.001$ ), chemical oxygen demand (COD, $\mathrm{r}=-0.64, \mathrm{P}<0.001$ ), total suspended solids (TSS, $\mathrm{r}=$ $-0.86, \mathrm{P}<0.001)$ and Orthophosphate $\left(\mathrm{H}_{2} \mathrm{PO}_{4}^{-}: \mathrm{r}=-0.85, \mathrm{P}<0.001\right)$, this shows of the impacts of anthropogenic activities on the survival of species (Downstream BF5-BF6) while the Biotic index (IBGN) was significantly and positively correlated with dissolved oxygen (DO: $r=0.92, \mathrm{P}<0.001$ ) increase in oxygen dissolved in water promotes the existence of the species.

With regard to the diversity index, it was influenced by TSS and conductivity. For Shannon's index, it was significantly $(\mathrm{P}<0.001)$ influenced by TSS (CA: $r=$ -0.84 ), temperature (CA: $r=-0.69$ ), and conductivity (CA: $r=-0.83$ ). Therefore, the richness and diversity indices were generally influenced by TSS, COD, $\mathrm{BOD}$ and the conductivity of the river water, because the increase of the COD, TSS, BOD in the downstream sites (Table 2) leads to the reduction of Taxonomic richness and diversity index (Table 6).

Members of the order Ephemeroptera are considered to be sensitive to environmental stress and their presence signified relatively clean conditions [56]. The numbers of Ephemeroptera taxa were highest at the upstream; they were absent at the downstream (Table 5). The downstream stations were dominated by Lumbriculus sp., Aulodrilus sp. and Tubifex sp. (Oligochaeta) and this worm species is known to be able to tolerate unfavorable conditions such as low DO and high pollutant concentrations [20] [57]. For example, a high density of oligochaetes is a good indication of organic pollution [58] and low DO concentrations had been related to sewage outfalls [55]. The order Oligochaeta also has a high tolerance to a variety of stresses and when they are present in high abundance, is a good indicator of pollution [59] [60]. Therefore, Lumbriculus variegatus is potential bioindicator for a polluted river ecosystem. This agreed with the suggestion by Yap et al., 2003 [61] for lumbriculus sp. found at the downstream of the River. Harrell and Smith 2002 [62] found evidence that some organic enrichment at the downstream of the River was indicated by the dominance of Tubifex and decreased oxygen concentrations. Trichoptera are potential bioindicators for the clean ecosystem since they could be found at the clean upstream stations (Stations 1 - 4) of the Boufekrane River. On the other hand, some chironomid sp. "sensitive" were found only at the upstream stations. The distribution of the benthic macroinvertebrates in the Boufekrane River could possibly remain in the clumped pattern for a period of time unless the river is disturbed by natural and anthropogenic activities.

Human activities may change the normal development of these fragile ecosystems, especially in the downstream of the Boufekrane River. The poor water quality at the downstream could be attributable to several man-induced activities such as urban runoff to surface river water due to direct or unregulated discharges in the Boufekrane River passing through populated regions. In addition to urban effluents, nearby light industries from oil palm mills, house-building, and agricultural pesticides could have strong influences on the macrobenthic 
invertebrates and cause severe variations in their assemblages. These organisms have different levels of sensitivity to pollution and many abiotic factors in the river ecosystem [63]. Use of the waters of the Boufekrane River for irrigation, mainly downstream, poses a risk of contamination by penetration of pollutants in groundwater.

The physicochemical data and the presence/absence of macrobenthic invertebrates in the upstream and downstream stations indicated in function of a combination of natural and anthropogenic influences. The hydrology of the river along the length of the watershed could be changed, but the most significant factor in changing the distribution of benthic macroinvertebrates is the anthropogenic inputs. This is well supported by the human activities found in the downstream of the river. The lack of obvious changes in the presence/absence of the macrobenthic invertebrates during the year of samplings indicated that the Boufekrane River was not highly fluctuating with regard to the seasonality of rainfall and dilution factor. The consistent presence of the resistance Tubifex sp. at the downstream stations indicated regular point sources of pollution discharge due to human activities and this causes the water quality deterioration. On the other hand, species sensitive to pollution such as Trichoptera and Ephemeroptera were present consistently at the clean water quality upstream ecosystem.

This indicated the natural habitats of the biotic species that truly reflected the assemblages and distribution of the benthic macroinvertebrates. The assemblages and distribution of the benthic macroinvertebrates frequently change in response to pollution stress in predictable ways. This is the basis for the development of biological criteria to evaluate anthropogenic influences [19] [55].

Gray [64] summarized the responses into three distinct categories: reduced diversity, increased domination by a single or group of opportunistic species, and reduced individual size. The first two were shown by the macrobenthic data of the downstream of the Boufekrane River. The polluted downstream had dominant species of oligochaete worms and reduced species diversity. The dominance of species with different levels of pollution tolerance found in the upstream and downstream stations indicated distinct environmental conditions, from the no polluted upstream to the polluted downstream. Individual species may vary in population density for a wide variety of reasons [59] [65] [66], indicating natural variations of biotic and abiotic factors of the Boufekrane River. The distribution of the benthic macroinvertebrates in the Boufekrane River could possibly remain in the clumped pattern for a period of time unless the river is disturbed by natural and anthropogenic activities. Natural variation in river conditions also played major roles in the macroinvertebrate community structure. Based on the multiple regression analysis, TSS, COD and electric conductivity were three physicochemical parameters identified as altering the benthic macroinvertebrate community, as indicated by the biodiversity indices.

Finally, the absence of sensitive benthic macroinvertebrates and the presence of the tolerant Tubifex sp. supported the classification of the downstream sta- 
tions as "polluted" by using the SEQ score system. This is in agreement with the report by the Sebou Agence (2006) that the rivers in basin were generally clean at the upstream and were either slightly polluted or polluted due to urban wastes and agricultural activities at the downstream. This has strengthened our ecotoxicological point of view that anthropogenic activities contributed to the changes in the distribution of the benthic macroinvertebrates in the Boufekrane River. In most circumstances anthropogenic sources of rivers include terrestrial sources from mining industries and urbanization along the rivers. The extent to which human activities have influenced the concentration of pollutants at a particular location is especially important to the local authority as it is fundamental to the need, or otherwise, for control of pollutants discharged in effluents and atmospheric emissions. The downstream parts of the Boufekrane River received wastewater from some densely populated areas and industries nearby and therefore it is important that the regulatory authorities should implement and enforce an appropriate strategy to monitor, regulate, and protect this area of the river.

\section{Conclusion}

The impacts of anthropogenic activities on the water quality, biodiversity, and distribution of benthic macroinvertebrates were noticeable. Compared to the pristine upstream stations, resistant benthic macroinvertebrates could be found only in the downstream of the Boufekrane River with poor and low water quality indices and "poor" diversity indices $H$ ' score. Therefore, the collection of certain macrobenthic species, particularly in polluted and non-polluted parts of a river indicated that they could be used as potential bioindicators for river pollution. These macrobenthic species can be used to establish biological criteria to classify the river ecosystem as being healthy or polluted. This information is very important to serve as a baseline study for the area to inform regulators of the conditions and how the use of bioindicators can assist in environmental monitoring and management of the area. Once the information on the life histories of the benthic macroinvertebrates from Morocco is lacking, our list of benthic macroinvertebrates found in the Boufekrane River is useful and more taxonomic work should be done for the identification of the organisms at the species level.

\section{Acknowledgements}

The authors thank the laboratory assistant Mr. Zarhouni M., Delegation of Health MEKNES and Pr. Addoli J., Pr. Douri F., for their help during the field samplings and laboratory analysis.

\section{References}

[1] Food and Agriculture Organization (FOA) (2010) The State of World Fisheries and Aquaculture. FAO Fisheries and Aquaculture Department, Rome.

[2] United Nations (1992) Report of the United Nations Conference on Environment and Development. Resolutions Adopted by the Conference. Vol. 1. United Nations, Rio de Janeiro.

[3] Xu, J. (2004) A Study of Anthropogenic Seasonal Rivers in China. Catena, 55, 17-32. 
[4] Cairns, J. and Der Schalie, W.H.V.D. (1980) Review Paper: Biological Monitoring. Part Early Warning Systems. Water Research, 14, 1179-1196.

[5] Cairns, J. (1981) Review Paper: Biological Monitoring. Part VI Future Needs. Water Research, 15, 941-952.

[6] Matthews, R., Buikema, A.L., Cairns, J. and Rodgers, J.H. (1982) Review Paper: Biological Monitoring. Part IIA-Receiving System Functional Methods, Relationships and Indices. Water Research, 16, 129-139.

[7] Herricks, E. and Cairns, J. (1982) Biological Monitoring. Part III Receiving System Methodology Based on Community Structure. Water Research, 16, 141-153.

[8] Buikema, A.L., Niederlehner, B.R. and Cairn, J. (1982) Biological Monitoring. Part IV Toxicity Testing. Water Research, 16, 239-262.

[9] Cherry, D.S. and Cairns, J. (1982) Biological Monitoring. Part V Preference and Avoidance Studies. Water Research, 16, 263-301.

[10] Arienzo, M., Adamo, P., Bianco, M.R. and Violante, P. (2001) Impact of Land Use and Urban Runoff on the Contamination of the Sarno River Basin in Southern Italy. Water, Air, \& Soil Pollution, 131, 349-366. https://doi.org/10.1023/A:1011908019933

[11] Ogbeibu, A.E. and Oribhabor, B.J. (2002) Ecological Impact of River Impoundment Using Benthic Macro-Invertebrates as Indicators. Water Research, 36, 2427-2436.

[12] Mason, C.F. and Parr, B.L. (2003) Long-Term Trends in Water Quality and Their Impact on Macroinvertebrate Assemblages in Eutrophic Lowland Rivers. Water Research, 37, 2969-2979.

[13] Armitage, D., Moss, D., Wright, J.F. and Furse, M. (1983) The Performance of a New Biological Water Quality Score System Based on Macro-Invertebrates over a Wide Range of Unpolluted Running-Water Sites. Water Research, 17, 333-347.

[14] Hellawell, J.M. (1986) Biological Indicators of Freshwater Pollution and Environmental Management. In: Melanby, K., Ed., Pollution Monitoring Series, 546 p. https://doi.org/10.1007/978-94-009-4315-5

[15] Metcalfe, J.L. (1989) Biological Water Quality Assessment of Running Waters Based on Macro-Invertebrate Communities: History and Present Status in Europe. Environmental Pollution, 60, 101-139.

[16] Wright, J.F., Furse, M.T., Armitage, P.D. and Moss, D. (1993) New Procedures for Identifying Running-Water Sites Subject to Environmental Stress and for Evaluating Sites for Conservation, Based on the Macro-Invertebrate Fauna. Arch Hydrobiologia, 127, 319-326.

[17] Pinel-Alloul, M.G., Lapierre, L. and Willsie, A. (1996) Macrobenthic Community as a Biological Indicator of Ecological and Toxicological Factors in Lake Saint-Francois (Quebec). Environmental Pollution, 91, 65-68.

[18] MacNeil, C., Dick, A., Bigsby, E., Elwood, R.W., Montgomery, I., Gibbins, N. and Kelly, W. (2002) The Validity of the Gammarus: Asellusratio as an Index of Organic Pollution: Abiotic and Biotic Influences. Water Research, 36, 75-84.

[19] Nedeau, E.J., Merritt, R.W. and Kaufman, M.G. (2003) The Effect of an Industrial Effluent on an Urban Stream Benthic Community: Water Quality vs. Habitat Quality. Environmental Pollution, 123, 1-13.

[20] Parinet, A., Boukari, S.O.B. and Adima, A. (2005) Evaluation de l'etat d'une eau de riviere par analyse multidimentionnelle utilisant certains paramétres caratéristiques de la matiére organique dissoute. Revue des sciences de Peau, 18, 133-163.

[21] Crosa, G., Froebrich, J., Nikolayenko, V., Stefani, F., Galli, P. and Calamari, D. 
(2006) Spatial and Seasonal Variations in the Water Quality of the Amu Darya River (Central Asia). Water Research, 40, 2237-2245.

[22] Sage, L., Bennasser, L., Steiman, R. and Seigle-Murandi, F. (1997) Fungal Microflora Biodiversity as a Function of Pollution in Oued Sebou (Morocco). Chemosphere, 35, 751-759.

[23] Khamar, M., Bouya, D. and Ronneau, C. (2000) Pollution metallique et organique des eaux et des sediments d'un cours d'eau marocain par les rejets liquides urbains. Water Quality Research Journal, 35, 147-161.

[24] Azzaoui, S., El Hanbali, M. and Leblanc, M. (2002) Copper, Lead, Iron and Manganese in the Sebou Drainage Basin; Sources and Impact on Surface Water Quality. Water Quality Research Journal, 37, 773-784.

[25] MCI (2009) Ministére du Commerce et de l'Industrie, Direction Générale de l'Industrie, Etude de l'impact des rejets industriels sur la qualite des eaux de l'oued Sebou, rapport de synthese. Scandia Consults International AB, Juillet 2009.

[26] P.D.M. (2004) Plan Directeur Wilaya de Meknés. Rapport, Genève, 180 p.

[27] Rodier, J. (1984) L'analyse de l'eau: Eaux naturelles, eaux résiduaires, eau de mer. Dunod, Paris.

[28] Association française de normalisation (AFNOR) NF/Environneemnt-1992.

[29] Baroudi, M. (1984) Contribution à l'étude des oligochètes, étude taxonomique de quelques genres d'enchytraida, étude faunistiques des oligochètes aquatiques du Maroc. Thése $3^{\circ}$ cycle Univ. Moulay Ismail Fac. Sci. Meknès.

[30] Lafont, M. (1983) Introduction pratique à la systématique des organismes des eaux continentale françaises. 3: Annélides Oligochètes. Bulletin mensuel de la Société linnéenne de Lyon, 52, 108-135. https://doi.org/10.3406/linly.1983.10583

[31] Amors, C. (1984) Crustacés, Introduction pratique à la systématique des organismes des eaux continentales françaises. Bulletin mensuel de la Société linnéenne de Lyon, 53-63.

[32] Ramdani, M., Dakki, M., Kharboua, M. and EL Aagbani, A. (1987) Les Gastéropodes dulcicoles du Maroc, inventaire commenté. Bulletin de PInstitut Scientifique de Rabat, 11, 135-140.

[33] Tachet, H., Richoux, P., Bournaud, M. and Usseglio-Polatera, P. (2000) Invertébrés d'eau douce. Systématique, Biologie, Ecologie. CNRS Editions, Paris, 588.

[34] Aguesse and Dakki (1982) Les Odonates de l'Europe Occidentale, du Nord de l'Afrique et des Îles Atlantiques. Masson Cie, Paris, 258 p.

[35] Vigneux, E., Keith, P., Noël, P.Y., et al. (1993) Atlas préliminaire des Crustacés Décapodes d'eau douce de France. Patrimoines Naturels, 14, 1-56.

[36] Berrahou, A., Cellot, B. and Richter, P. (2002) Les macroinvertébrées benthiques de la Moulouya (Maroc). Bull. Ecol., 223-234.

[37] Bouzidi, A. (1989) Recherches hydrobiologiques sur le cours d'eau des massifs du Haut-Atlas. Bioécologie des macroinvértébrés et distribution spatiale des peuplements. Doctorat d’État Uni. Aix-Marseille, fac. Sci. Tech. Sai-Jérôme, 190 p.

[38] Vergon, J.-P. and Bourgeois, C. (1993) Introduction pratique à la systématique des organismes des eaux continentales françaises 10: Diptères chironomides (larves aquatiques) T. 1: Caractères généraux, sousfamilles et tribus. Bull. Mens. Soc. Linn. Lyon, 62, 101-132.

[39] Dakki, M. (1992) Etude National sur la biodiversité Faune aquatique continentale (Invertébrés et Poissons) Projet PNUE/GEF/6105-92, 121.

[40] Beauger, A. (2008) Bio-évaluation de la qualité de l'eau: établissement d'un 
protocole d'échantillonnage simplifié, basé sur la collecte des macroinvertébrés benthiques sur les seuils des rivières à charge de fond graveleuse. Biodiversité et Ecologie. Université Blaise Pascal - Clermont-Ferrand II; Université d'Auvergne Clermont-Ferrand I, 2008. Français. https://tel.archives-ouvertes.fr/tel-00730658/document

[41] Ludwig, J.A. and Reynolds, J.F. (1988) Statistical Ecology: A Primer on Methods and Computing. Wiley, New York, 85-106.

[42] Chevenet, F. (1994) A Fuzzy Coding Approach for the Analysis of Long-Term Ecological Data. Freshwater Biology, 31, 295-309. https://doi.org/10.1111/j.1365-2427.1994.tb01742.x

[43] Chahlaoui, A., Cugny, P., Lek, S., Zaid, A. and Ramdani, M. (1997) Analyse quantitative de la qualité de l'eau de l'oued Boufekrane (Maroc). Bulletin de la Société d Histoire Naturelle de Toulouse, 131, 71-76.

[44] Vega, M., Pardo, R., Barrado, E. and Deban, L. (1998) Assessment of Seasonal and Polluting Effects on the Quality of River Water by Exploratory Data Analysis. Water Research, 32, 3581-3592.

[45] WHO (1984) International Standards for Drinking Water. 3rd Guidelines for Drinking Water Quality. Vol. 2: Health Criteria and Other Supporting Information. World Health Organization, Geneva.

[46] DeZuane, J. (1997) Handbook of Drinking Water Quality. 2nd Edition, John Wiley and Sons, Hoboken.

[47] Bournaud, M. and Keck, G. (1980) Les prélbvements de macroinvertébrés benthiques en tant que revelateurs de la physionornie d'une rivibre. Annls Limnologie, 16, 55-75. https://doi.org/10.1051/limn/1980009

[48] Brodnjak, D., Dobnik, D., Novi, M. and Zupan, J. (2002) Chemometrics charactersation of the Quality of River Water. Analytica Chimica Acta, 462, 87-100.

[49] Gilpin, B., James, T., Nourozi, F., Saunders, D., Scholes, P. and Savill, M. (2003) The Use of Chemical and Molecular Microbial Indicators for Faecal Source Identification. Water Science \& Technology, 47, 39-43.

[50] Cherghou, S., Yaâkoubi, F., Benabid, M. and Badri, A. (2002) Contribution à l'étude du régime alimentairedu barbeau (Barbus barbus callensis Valenciennes, 1842) d'un cours d'eau du Moyen-Atlas (Maroc): Oued Boufekrane. Revue des sciences de P eau, 15, 153-163. https://doi.org/10.7202/705443ar

[51] De Lagarde, J. (1995) Initiation à l'analyse de données. 3 ième Edition, Dunod, Paris.

[52] Essahale, A. and Karrouch, L. (2015) Contribution to the Study of Oil Mills Impact on the Environment in el hajeb Province. Archives des Maladies Professionnelles et de P Environnement, 76, 355-365.

http://www.sciencedirect.com/science/article/pii/S1775878515001617

[53] Gaufin, A.R. (1973) Use of Aquatic Invertebrates in the Assessment of Water Quality. In: Cairns, J.J. and Dickson, K.L., Eds., Biological Methods for the Assessment of Water Quality, STP 528, American Society for Testing and Materials, Philadelphia, 96-116. https://doi.org/10.1520/stp34719s

[54] Teles, L.F.O. (1994) A New Methodology for Biological Water Quality Assessment. International Association of Theoretical \& Applied Limnology, 25, 1942-1944.

[55] Boyle, T.P. and Fraleigh, H.D. (2003) Natural and Anthropogenic Factors Affecting the Structure of the Structure of the Benthic Macro-Invertebrate Community in an Effluent-Dominated Reach of the Santa Cruz River, AZ. Ecological Indicators, 3, 93 117. 
[56] Bustos-Baez, S. and Frid, C.C. (2003) Using Indicator Species to Assess the State of Macro-Benthic Communities. Hydrobiologia, 496,299-309. https://doi.org/10.1023/A:1026169520547

[57] Brinkhurst, R.O. (1967) The Distribution of Aquatic Oligochaetes in Saginaw Bay, Lake Huron. Limnology and Oceanography, 12, 137-143. https://doi.org/10.4319/lo.1967.12.1.0137

[58] Slepukhina, T.D. (1984) Comparison of Different Methods of Water Quality Evaluation by Means of Oligochaetes. Hydrobiology, 115, 183-186. https://doi.org/10.1007/BF00027914

[59] Barbour, M.T., Gerritsen, J., Snyder, B.D. and Stribling, J.B. (1999) Rapid Bioassessment Protocols for Use in Streams and Wadeable Rivers: Periphyton, Benthic Macro-Invertebrates and Fish. 2nd Edition, Office of Water, US Environmental Protection Agency, Washington DC, EPA-841-B-99-002.

[60] Castella, E., Husson, O. and Hakon, A. (2001) Macrobenthic Invertebrate Richness and Composition along a Latitudinal Gradient of European Glacier-Fed Streams. Freshwater Biology, 46, 1811-1831. https://doi.org/10.1046/j.1365-2427.2001.00860.x

[61] Yap, K., Rahim Ismail, A., Ismail, A. and Tan, S.G. (2003) Species Diversity of Macrobenthic Invertebrates in the Semenyih River, Peninsular Malaysia. Pertanika Journal of Tropical Agricultural Science, 26, 139-146.

[62] Harrel, R. and Smith, S. (2002) Macrobenthic Community Structure before, during and after Implementation of the Clean Water Act in the Neches River Estuary (Texas). Hydrobiologia, 474, 213-222. https://doi.org/10.1023/A:1016596123558

[63] Rosenberg, D.M. and Resh, V.H. (1993) Freshwater Biomonitoring and Benthic Macro-Invertebrates. Chapman and Hall, New York, 488 p.

[64] Gray, J.S. (1989) Effects of the Environmental Stress on Species Rich Assemblages. Biological Journal of the Linnean Society, 37, 19-39. https://doi.org/10.1111/j.1095-8312.1989.tb02003.x

[65] Kerans, B.L., Karr, J.R. and Ahlstedt, S.A. (1992) Aquatic Invertebrate Assemblages: Spatial and Temporal Differences among Sampling Protocols. Journal of the North American Benthological Society, 11, 390. https://doi.org/10.2307/1467559

[66] Mucha, A.P., Vasconcelos, M.T.S.D. and Bordalo, A.A. (2004) Vertical Distribution of the Macrobenthic Community and Its Relationships to Trace Metals and Natural Sediment Characteristics in the Lower Douro Estuary, Portugal. Estuarine, Coastal and Shelf Science, 59, 663-673. 
Submit or recommend next manuscript to SCIRP and we will provide best service for you:

Accepting pre-submission inquiries through Email, Facebook, LinkedIn, Twitter, etc. A wide selection of journals (inclusive of 9 subjects, more than 200 journals)

Providing 24-hour high-quality service

User-friendly online submission system

Fair and swift peer-review system

Efficient typesetting and proofreading procedure

Display of the result of downloads and visits, as well as the number of cited articles Maximum dissemination of your research work

Submit your manuscript at: http://papersubmission.scirp.org/

Or contact gep@scirp.org 